\title{
Toxic Leadership, Teachers' Job Satisfaction and Organisational Commitment in Lagos State Tertiary Institutions, Nigeria
}

\author{
Nurudeen Olalekan Orunbon ${ }^{1}$, Rasaki Olanrewaju Lawal ${ }^{2}$, Margaret Modupe Isaac-Philips ${ }^{3}$, \\ Rafiyat Iyabo Salaudeen ${ }^{4}$ \\ ${ }^{1,3}$ Department of Educational Management, Lagos State University, Ojo, Lagos, Nigeria \\ ${ }^{2}$ Department of Educational Foundations and Management, Michael Otedola College of Primary Education, Lagos, Nigeria
}

${ }^{4}$ Community Senior Secondary School, Agric School Complex, Ojo, Lagos, Nigeria

\section{ARTICLE INFO}

\section{Article history:}

Received: 25 Nov 2021

Revised: 13 Jan 2022

Accepted: 16 Jan 2022

Published online: 24 Jan 2022

Keywords:

Toxic Leadership

Job satisfaction

Organisational commitment

\begin{abstract}
A B S T R A C T
Employee job satisfaction and organisational commitment are directly influenced by leadership styles. Despite the fact that the good elements of leadership have already been explored, the bad sides of leadership must be addressed as well. This study examined the relationship between school toxic leadership, teachers' job satisfaction and organisational commitment in Lagos State tertiary institutions. Two hypotheses were set to serve as guides for the study. Correlational and descriptive research designs were adopted while the population comprised all lecturers in Lagos State owned tertiary institutions. The sample size was 240 lecturers after stratifying the population into the institutions nomenclature and thereafter selected through purposive sampling technique. Analysis was carried out using inferential statistics of Pearsons Product-Moment Correlation Analysis. Findings indicated that a negative relationship existed between toxic leadership and teachers' job satisfaction in Lagos State tertiary institutions and also a negative relationship existed between toxic leadership and organisational commitment in Lagos State tertiary institutions. According to the findings of the study, toxic leadership exists in Lagos State higher institutions. The study recommended that before being placed in leadership roles, tertiary institution lecturers should be exposed to leadership development training and opportunities.
\end{abstract}

\section{Introduction}

Effective leadership is critical to every organisation's long-term health and success. This is true across all sectors, including schools, government institutions, and community organisations. Leaders provide the vision and direction that enable resources, labour, and effort to be mobilized to achieve goals. The leader's

\footnotetext{
* Corresponding author.

E-mail: orunbon.nurudeeno@gmail.com
} 
influence, knowledge, and personal example provide the circumstances for the organisation and its members to be inspired, directed, and protected while they work to achieve their goals. The connection between leaders and followers must be built on trust and respect if school operations are to thrive while maintaining organisational health. Toxic leaders can survive, and in some cases thrive, in organisations because of the human aspect of leadership, especially the need for resource control, risk calculation, and performance (Leet, 2011).

The majority of toxic leadership literature rightly focuses on the leader's damaging personal characteristics. On the other hand, their toxicity would be restricted in the absence of a conducive atmosphere and complicit subordinates. Volatility, perceived threats, and inadequate institutional practices, and cultural norms are all environmental risk factors. On the other hand, subordinates who allow toxicity are classified as either conformers or colluders, with each attempting to tolerate or exploit the situation without addressing the toxic leader directly. In the last several years, the globe has witnessed a number of big organisation failures, including school failures, all of which have resulted in economic and personnel misery. There has clearly been a huge leadership failure that has resulted in the demise of key institutions. The question is whether these failures are the consequence of intentional, willful violations of proper leadership practice or just arrogant, dysfunctional leaders' ineptitude. Effective school leadership is critical for improving educational effectiveness and equality. As a result, leadership may be the spark for the system's improvement and overall success. Leadership in performance was the main link to target achievement and the degradation of most tertiary institutions in most Nigerian states.

Different leadership literature suggests that the toxic leadership issue is caused by a variety of actions rather than just a lack of effective leadership. To comprehend the usefulness and growth of the leadership philosophy, it is necessary to investigate the dark side of leadership (Einarsen, Aasland, \& Skogstad, 2007). Leaders who use bullying, manipulation, greed, lying, and abuse of followers are demonstrating the negative side of leadership behaviour by prioritizing their own interests over the legitimate interests of the organisation (Kellerman, 2004). As a result, the toxic acts of leaders have an effect on both employees and the organisation. Researchers have previously highlighted the negative effects of the dark side of leadership on employees (Schyns \& Schilling, 2013; Naseer, Raja, Syed, Donia, \& Darr, 2016), resulting in a decrease in job satisfaction (Tepper, 2000; Tepper et al., 2009), as well as an increase in employee tension (Tepper, 2000), turnover, absenteeism, inefficiency (Aryee, Chen, Sun, \& Debrah, 2007).

Toxicity in leadership has a significant detrimental influence on both individuals and organisations. It has a catastrophic effect on academics, teaching and learning, and the institution as a whole in the academic setting. It has the potential to undermine the purpose of higher education institutions in society. Herbst and Mukhola's (2018) research findings support the existence of leadership toxicity in South Africa's higher education institutions, which is associated with poor outcomes. Suggested by the findings that toxic leaders in higher education lack a feeling of trust, knowledge of academic administration, and a fundamental 
understanding of human interactions. It is unclear whether this indicates a lack of understanding and purpose for being in academic leadership in relation to the reason for academic institutions' existence in society.

Toxicity in any academic setting has the ability to stifle effective teaching and learning, as well as academic knowledge generation (Giroux, 2015). Toxicity has no little room for assisting colleagues who are striving to achieve the best levels of research and teaching in order to compete with other international institutions. It is, nevertheless, capable of developing methods to frustrate academics to the point of mental anguish. This sort of leadership undermines the entire concept of intellectual space, in which research creates new ground and allows both researchers and institutions to take the lead in research. A location that is not favourable to knowledge production will also be unsuitable for teaching young brains to move and build their country's economy. Employees in higher education institutions must be free of toxicity in order for them to perform properly. Therefore, "toxic leadership is associated with the decreased employee performance, increased level of psychological distress and low level of job satisfaction and commitment" (Hussein et al., 2018:32).

\section{Statement of the Problem}

People who hold leadership roles in higher institutions are assumed to have a positive attitude toward teachers and their institutions. Positive leaders are also considered to emphasize components of motivation for employees to attain goals and inspirations to do more than they previously thought possible (Samier \& Schmidt 2010). It has been thought that every leader in their different leadership positions has the goal of promoting and expanding their institution's stated goals, which empowers everyone involved. These beliefs are also based on the notion that leadership entails the responsibility of driving innovation, development, and encouraging people to enhance their performance.

However, what happens in fact does not always match the assumption. In this sense, there is sufficient empirical proof that toxicity exists in the academic environment (Herbst \& Conradie 2011; Herbst \& Mukhola; Mafini 2014; Ngcamu 2015 and Orunbon, 2021). Working and giving birth to new ideas in an academic setting, where knowledge generation is vital, becomes difficult, if not impossible, under toxic leadership. Both the personnel and the institution as a whole suffer as a result of this. Bad leadership has the potential to erode collegiality and teamwork, as well as demotivate and, ultimately, eliminate talents that are required for an institution's productivity and success (Baloyi, 2020).

\section{Literature Review}

\section{Concept of Toxic Leadership}

Dr. Marcia Lynn Whicker's (Whicker, 1996) research was the first to use the phrase "toxic leadership," which is damaging to morale, productivity, and organisational performance (Maxwell, 2015). Lynnn identified three types of 
leadership: stable, changing, and toxic, and she introduced the idea of toxic leadership into the literature (Doriane \& Manon, 2013) In the years afterwards, he has said that three out of every ten persons in positions of leadership might be toxic leaders (Armitage, 2015). Toxic leaders, who spread their poison by imposing repeated control on their people, poison their employees' unique, passionate, and imaginative expression, harming both the employees and the company (Indradevi, 2016). Furthermore, studies reveal that toxic leaders have a long-term detrimental influence on the health and well-being of their workforce (Hitchcock, 2015).

Toxic leaders engage in behaviors that lead them to believe they are better or more capable (Tavanti, 2011), are prone to power and authority abuse (Hadadian \& Sayadpour, 2018), are narcissistic, paranoid, maladaptive, and insatiable (Hadadian \& Sayadpour, 2018), are devoid of empathy, narcissistic, paranoid, maladaptive, and insatiable (Lipman-Blumen, 2005). Webster, Brough, and Daly (2016) described toxic leadership as those who have a habit of manipulating and displaying threatening, arrogant, and unethical behavior toward others in a systematic and repeatable manner. Toxic leaders, on the other hand, have a selfrepeating communication style in which they provide information under the guise of secrecy or what they need to know, have multiple untargeted meetings, and make numerous phone calls (Weberg \& Fuller, 2019).

\section{Job Satisfaction}

The physiological, psychological, and environmental factors that lead to employees being happy with their occupations are referred to as job satisfaction (Raziq \& Maulabakhsh, 2015). Individuals' attitudes and actions regarding their occupations are characterized as work attitudes and behaviours. Attitudes are the positive or bad feelings that arise in people's circumstances. Job contentment happens when people have favorable attitudes in their workplaces, whereas job dissatisfaction occurs when they have negative views (Huang, et al., 2016).

Job satisfaction, according to Locke (1976), is described as "satisfaction or a good emotional state arising from the appraisal of individuals' work experiences," and it is increased if people are valued for their work.

\section{Organisational Commitment}

Employees' ability to express themselves and feel a sense of belonging to the organisation in which they work (Mowday, Porter, \& Steers, 1982); employee's efforts to stay in the organisation and help the organisation improve (McDonald \& Makin, 2000); employee's efforts to stay in the organisation and help the organisation improve, all revolves around organisational commitment. Organisational commitment is essential when it comes to sustaining organisational efficiency and productivity. Employees that have a high level of organisational commitment prioritize the organisation's interests over their own, are more compatible with the organisation and its other employees, and are more productive inside it. Employees with low levels of organisational commitment often operate in their own best interests, do not come on time, are frequently 
absent, wish to quit their jobs, are unable to effectively accomplish the duties allocated to them, and do not act in the best interests of the organisation (Durusu, 2019).

\section{Effects of Toxic Leadership on Job Satisfaction}

Job satisfaction refers to a person's views and evaluations of his or her job, which are impacted by the individual's specific circumstances, such as needs, values, and expectations (Buitendach \& Rothmann, 2009). Toxic leadership has a statistically significant negative connection with work satisfaction, according to Mehta and Maheshwari (2013). Schmidt (2014), who found a statistically unfavorable link between toxic leadership and work satisfaction on both individual and group level, backs up their findings. Toxic, disruptive, and dysfunctional leadership behavior, according to Kusy and Holloway (2009) and Tepper (2007), has a detrimental influence on employee job satisfaction. The most essential element in determining worker motivation, effectiveness, retention, and performance is job satisfaction (Shaju \& Subhashini, 2017). Improved performance has a favorable effect on work satisfaction. This is based on the social exchange theory (Cropanzano \& Mitchell, 2005), which proposes that social behavior is the consequence of an exchange process with the goal of maximizing benefits and minimizing costs. Employees will be more likely to perform well at work if they are happy with their work environment and leadership, resulting in improved job performance, good work values, high levels of employee motivation, and decreased rates of absenteeism, attrition, and burnout (Shaju \& Subhashini, 2017).

\section{Effects of Toxic Leadership on Organisational Commitment}

In terms of bad leadership behaviours, research has demonstrated that abusive leadership has a detrimental impact on commitment (Rayner and Cooper, 1997; Tepper, 2000; Burris, Detert \& Chiaburu, 2008). Destructive leadership, according to Weaver and Yancy (2010), is inversely connected to workers' emotional commitment and positively related to workers' willingness to quit their organisation. According to Mehta and Maheshwari's (2013) research, there is a substantial negative connection between different toxic leadership characteristics and organisational commitment variables. Negativity in the workplace has been shown to have a detrimental influence on employee performance (Padilla, Hogan \& Kaiser, 2007). Employee psychological problems such as stress, depression, and anxiety, according to extensive study, can have a negative impact on an organisation's performance and production. According to Harris, Kacmar, and Zivnuska's (2007) research, abusive leadership is linked to lower employee work performance. Employees who work with toxic bosses have two options: comply or go. Those who want to stay in the organisation hold out hope that the situation will improve. Some of them may respond by merely being partially present. In other words, their commitment to their jobs and their ties to the organisation may be shaky. Commitment to an organisation that enables harmful leadership should, in theory, be low, because followers may believe the organisation is failing to safeguard them (Burris, Detert, \& Chiaburu, 2008; Schyns \& Schilling, 2013). As a result, employees' loyalty to the organisation may dwindle. Employees may 
form emotional attachments to their organisations, but they may also feel devoted to their bosses, according to study (Clugston et al., 2000; Siders et al., 2001).

\section{Research Hypotheses}

The following null hypotheses were tested in this study:

Ho1: There is no significant relationship between toxic leadership and teacher job satisfaction in Lagos State tertiary institutions.

Ho2: There is no significant relationship between toxic leadership and organisational commitment in Lagos State tertiary institutions.

\section{Methodology}

This study was carried out in order to understand the correlational relationship between the toxic leadership, teacher job satisfaction and organisational commitment in Lagos State tertiary institutions. It is assumed that by making assumptions about the way things are and provoking behaviour, it is possible to provide concrete and reliable explanations of an identified problem or circumstance (Wallen \& Hyun, 2011). Therefore, this research is able to establish the relationship between toxic leadership, job satisfaction and organisational commitment of teachers in public tertiary institutions of Lagos State. The study adopted correlational research design; this is because the study examined the nature of relationship between toxic leadership, teachers' job satisfaction and organisational commitment in Lagos State public tertiary institutions. The study population included lecturers in all four tertiary institutions operated by the Lagos State Government. Institutions included Lagos State University, Ojo, Lagos State Polytechnic, Ikorodu, Adeniran Ogunsanya College of Education, Oto-Ijankin and Michael Otedola College of Primary Education, Noforija-Epe.

Using the purposive sampling approach, the study's sample comprised of one university, one polytechnic, and one institution of education that made up the study's population in Lagos State. As a result, a multistage sampling process was utilized to pick Departments from each of the sampled public tertiary institutions, giving each Faculty/School and Department a chance to be chosen. Four Faculties/Schools were selected using a disproportionate stratified sampling technique from each sampled public tertiary institution in Lagos State, and three Departments were selected using a simple random sampling technique within each Faculty/School, for a total of 12 Departments per sampled public tertiary institution. In addition, ten academic staff members were chosen at random from each of the departments studied. The sample for this study consisted of 240 academic employees from public tertiary institutions in Lagos State, Nigeria, who had worked there for a minimum of 3-5 years and had never held the post of HOD.

A self-designed tool entitled "Toxic Leadership, Teachers Job Satisfaction and Organisational Commitment Questionnaire for Lecturers TLTJSAOCQL. The questionnaire comprised of two parts: A and B. Section A included items on the 
personal data of respondents who are academic workers. Section B consisted of 18 comments on toxic leadership, teacher job satisfaction and organisational commitment in Lagos State tertiary institutions. This questionnaire requested for information from respondents on toxic leadership, teacher job satisfaction and organisational commitment at their different institutions. The Four-point Likertscale was used. As a rating scale for the answers, the following corresponding ratings were adopted: Very True (VT)-4; True (T)-3; Untrue (U)-2 and Very Untrue (VU)-1. The questionnaire was constructed by the researcher with the assistance of experts in the field of Measurement and Evaluation and others in the Department of Educational Management in Lagos State University. Items on the instruments were made to cover the research hypotheses. The responses in the form of suggestions and amendments from these experts led to the modification of some statements and elimination of some items. Hence, this ensured both content and face validity.

Using Cronbach's Alpha Coefficient, the questionnaire was pilot tested to establish reliability. The questionnaires were administered on 24 academic staff who was part of the population of the study but not part of the sample. Cronbach's Alpha Coefficient Analysis was used to determine the reliability of Toxic Leadership, Teachers' Job Satisfaction and Organisational Commitment Questionnaire for Lecturers (TLTJSAOCQL). The coefficient obtained was 0.864 . Thus, the questionnaire was found substantially reliable. The researcher visited each sampled tertiary institutions with two research assistants who were specially trained in instrument administration and data collection to administer the questionnaire to the academic staff of each selected tertiary institution for the study. To test the two hypotheses, Pearson's Product-Moment Correlation Coefficient was used, as it is intended to calculate the relationship between the dependent variable and independent variables. With the aid of the Statistical Package for Social Sciences (SPSS) 20.0, the formulated hypotheses were tested at a level of significance of 0.05 .

\section{Data Analysis}

The Statistical Package for Social Science (SPSS) (version 24.0) programme interprets all data obtained quantitatively. The direction and strength of the relationship between the independent and dependent variables were determined by correlation analysis. A bivariate analysis, the correlation coefficient (r), calculates the intensity of the relation between two variables (Salkind, 2016). Pearson's correlation coefficient was used for this analysis. There was one independent variable in each hypothesis and one dependent variable. 


\section{Results and Discussion}

Table 1. Correlation Showing Relationship Between Toxic Leadership and Teachers' Job Satisfaction in Lagos State Public Tertiary Institutions

\begin{tabular}{llrr}
\hline & & $\begin{array}{c}\text { Teacher Job } \\
\text { Satisfaction }\end{array}$ & $\begin{array}{r}\text { Toxic } \\
\text { Leadership }\end{array}$ \\
\hline Teacher Job & Pearson Correlation & 1 & $.719(* *)$ \\
Satisfaction & Sig. (2-tailed) & & .000 \\
& $\mathrm{~N}$ & 200 & 200 \\
& & & \\
& & $.719(* *)$ & \\
Toxic leadership & Pearson Correlation & .000 & 200 \\
& Sig. (2-tailed) & 200 & \\
& $\mathrm{~N}$ & & \\
& & & \\
\end{tabular}

** Correlation was significant at the 0.01 level (2-tailed).

Table 1 illustrates that the Pearson's Correlation $r=0.719$ computed for toxic leadership and teacher job satisfaction in Lagos State tertiary institutions with pvalue $=0.000$ which is less than Alpha $=0.01$. This implies that toxic leadership behaviour does significantly influenced teacher job satisfaction in Lagos State tertiary institutions. This hypothesis is therefore rejected. Thus, confirming the alternative hypothesis that there is a significant relationship between toxic leadership and teacher job satisfaction in Lagos State tertiary institutions.

Table 2. Correlation Showing Relationship Between Toxic Leadership And Organisational Commitment In Lagos State Public Tertiary Institutions

\begin{tabular}{llrr}
\hline & & $\begin{array}{r}\text { Teacher Job } \\
\text { Satisfaction }\end{array}$ & $\begin{array}{r}\text { Toxic } \\
\text { Leadership }\end{array}$ \\
\hline Teacher Job & Pearson Correlation & 1 & $.823(* *)$ \\
Satisfaction & Sig. (2-tailed) & & .000 \\
& $\mathrm{~N}$ & 200 & 200 \\
& & & 1 \\
Toxic leadership & Pearson Correlation & $.823(* *)$ & \\
& Sig. (2-tailed) & & \\
& $\mathrm{N}$ & 2000 & 200 \\
\hline
\end{tabular}

** Correlation was significant at the 0.01 level (2-tailed).

Table 2 illustrates that the Pearson's Correlation $r=0.823$ computed for toxic leadership and organisational commitment in Lagos State tertiary institutions with $\mathrm{p}$-value $=0.000$ which is less than Alpha $=0.01$. The implication of this was that there was a significant influence of toxic leadership on organisational commitment of teachers in Lagos State public tertiary institutions. This means that higher the school toxic leadership behaviour of school leaders in tertiary institutions, the lower the organisational commitment of teachers. This hypothesis is therefore rejected. Thus, confirming the alternative hypothesis that there is a 
significant relationship between toxic leadership and organisational commitment in Lagos State public tertiary institutions.

\section{Discussion of Findings}

Toxic leadership has a statistically significant negative connection with job satisfaction, according to Mehta and Maheshwari (2013). Schmidt (2014), who found a statistically unfavorable link between toxic leadership and job satisfaction on both at individual and group level, backs up their findings. Toxic, disruptive, and dysfunctional leadership behaviour, according to Kusy and Holloway (2009) and Tepper (2007), has a detrimental influence on employee job satisfaction. The most essential element in determining worker motivation, effectiveness, retention, and performance is job satisfaction (Shaju \& Subhashini, 2017). Improved performance has a favourable effect on work satisfaction. Employees will be more likely to perform well at work if they are happy with their work environment and leadership, resulting in improved job performance, good work values, high levels of employee motivation, and decreased rates of absenteeism, attrition, and burnout (Shaju \& Subhashini, 2017).

Toxic leadership has a statistically significant negative connection with organisational commitment, according to Mehta and Maheshwari (2013). Schmidt's follow-up research discovered that toxic leadership has an impact on organisational commitment not just on an individual level but also on a collective level. Schmidt (2014) found a statistically negative link between the affective commitment dimension of organisational commitment and toxic leadership. Weaver and Yancy (2010) also discovered that disruptive leadership behaviour had a detrimental influence on workers' commitment to the organisation.

\section{Conclusion}

This research focuses on toxic leadership at tertiary institutions, since it has an impact on lecturers' work satisfaction and organisational commitment. This is not to say that people who take their place as school administrators are not capable of wreaking havoc on the school's operations. The greater a person's position in the school organisation, the more power they have if this power is utilized to adopt dysfunctional behaviours. The impacts might extend across the school organisation due to the legitimate or role authority that the individual has as a result of his or her position within the school organisation. To some extent, the study's findings suggest that toxic leaders are a result of their working environment. It goes without saying that the first place to look into school toxicity is with school leadership. Toxic leadership in any educational system affects teachers' job satisfaction and organisational commitment, as well as their faith in school leaders and the organisation, halting the school's academic improvement. 


\section{Recommendations}

Based on the findings of this study, the following recommendations are made.

1. Before the placement for leadership roles, tertiary institution lecturers should be exposed to professional development training and opportunities, particularly in leadership.

2. The tertiary institutions governing council members and other senate members that help in the selection of applicants for the leadership positions in tertiary institutions should also be individuals with good track records of leadership in their various areas of human endeavours.

3. To cope with the negative consequences of toxic leader's behaviours, tertiary institution lecturers' job satisfaction and organisational commitment should be strengthened. As a result, policies to increase lecturers' job satisfaction and organisational commitment should be formulated.

4. Toxic leaders should be identified and removed from educational institutions as soon as possible.

\section{References}

Armitage, A. (2015). The dark side: The poetics of toxic leadership. Advances in Developing Human Resources, 17(3), 376-390.

Aryee, S., Chen, Z. X., Sun, L. Y., \& Debrah, Y. A. (2007). Antecedents and outcomes of abusive supervision: test of a trickle-down model. Journal of Applied Psychology, 92(1), 191.

Baloyi, G. T. (2020). Toxicity of leadership and its impact on employees: Exploring the dynamics of leadership in an academic setting, HTS Teologiese Studies/Theological Studies 76(2), 1-8. a5949. https://doi.org/ 10.4102/hts.v76i2.5949

Baumeister, R. F., Bratslavsky, E., Finkenauer, C., \& Vohs, K. D. (2001). Bad is stronger than good. Review of General Psychology, 5(4), 323-370.

Buitendach, J.H., \& Rothmann, S. (2009). The validation of the Minnesota Job Satisfaction questionnaire in selected organisations in South Africa. South African Journal of Human Resource Management, 7(1), 1-8.

Burris, E. R., Detert, J. R., \& Chiaburu, D. S. (2008). Quitting before leaving: The mediating effects of psychological attachment and detachment on voice. Journal of Applied Psychology, 93(4), 912-922.

Clugston M, Howell J, and Dorfman P (2000) Does cultural socialization predict multiple bases and foci of commitment? Journal of Management 26: 5-30.

Cropanzano, R., \& Mitchell, M.S. (2005). Social exchange theory: An interdisciplinary review. Journal of Management, 31(6), 874-900. https://doi.org/10.1177/ 0149206305279602

Doriane, B., \& Manon, D. (2013). Toxic Leadership. Kalmar: Linnaeus University.

Durusu, H. (2019). Primary school teachers' perceptions of the mobbing levels, workplace friendship and their relationships with organisational 
commitment and examining them in terms of some variables. Educational Sciences Institute. Ankara: Gazi University.

Einarsen, S., Aasland, M. S., \& Skogstad, A. (2007). Destructive leadership behaviour: A definition and conceptual model. The Leadership Quarterly, 18(3), 207-216.

Fraenkel, J. R., Wallen., N. E., \& Hyun, H. (2011). How to Design and Evaluate Research in Education (8a ed.) McGraw-Hill Education.

Giroux, H., (2015). Neoliberalism's war against higher education and the role of public

intellectuals, Límite. Revista Interdisciplinaria de Filosofía Psicología 10(34), 5-16.

Hadadian, Z., \& Sayadpour, Z. (2018). Relationship between Toxic Leadership and Job Related Affective Well-Being:The Mediating Role of Job Stress. European Online Journal of Natural and Social Sciences, 7(1), 137-138.

Harris, K. J., Kacmar, K. M., \& Zivnuska, S. (2007). An investigation of abusive supervision as a predictor of performance and meaning of work as a moderator of the relationship. The Leadership Quarterly 18(3):252-263.

Herbst, T.H.H. \& Conradie, P.D.P. (2011). Leadership effectiveness in higher education: Managerial self-perceptions versus perceptions of others, South African Journal of Industrial Psychology 37(1), 11-14.

Herbst, T. H. H. \& Mukhola, M. S., (2018). Female leaders' experience of toxic leadership in higher education institutions in South Africa, in N. Delener \& C. Scheikert (eds.), Global business and technology association: 20th international conference, GBATA proceedings, Bangkok, Thailand, July 3-7, 2018, pp. 183-193.

Huang, Y., Lee, J., McFadden, A., Murphy, L., Robertson, M., Cheung, J., \& Zohar, D. (2016). Beyond safety outcomes: An investigation of the impact of safety climate on job satisfaction, employee engagement and turnover using social exchange theory as the theoretical framework. Applied Ergonomics, 55, 248-257.

Hussein, G.A.S., Wang, H., Hesham, M.A.H. \& Madina, K., (2018) Dark leadership impact on psychological well-being and work-family conflict: Implications for project success of Bahrain companies. Journal of International Business Research and Marketing 3(3), 32-39.

Indradevi, R. (2016). Toxic Leadership over the Years-A Review. Purushartha: $A$ Journal of Management Ethics and Spirituality, 9(1), 107.

Kellerman, B. (2004). Bad leadership: What it is, how it happens, why it matters. Harvard Business Press. Kelloway, E. K., Mullen, J., \& Francis, L. (2006). Divergent effects of transformational and passive leadership on employee safety. Journal of Occupational Health Psychology, 11(1), 76.

Kusy, M., \& Holloway, E. (2009). Toxic workplace: Managing toxic personalities and their systems of power. San Francisco, CA: Jossey-Bass.

Leet, E. (2011). The impact of Toxic or Severe Dysfunctional Leadership has on the effectiveness of an organisation. Unpublished Ph.D Thesis, Murdoch University.

Lipman-Blumen, J. (2010). Toxic leaders: They are plentiful. In G.R. Hickman (Ed), Leading Organisations: Perspectives for A New Era ( $2^{\text {nd }}$ ed). Washington, D,C: Sage. 
Locke, E. A. (1976). The nature and causes of job satisfaction. In Handbook of industrial and organisational psychology 1, 1297-1343.

Mafini, C. (2014) Tracking the employee satisfaction-life satisfaction binary: The case of South African academics. South African Journal of Industrial Psychology, 40(2), 1-11.

Maxwell, S. (2015). An exploration of human resource personnel and toxic leadership. Minneapolis: College of Management and Technology, Walden University.

McDonald, D. J., \& Makin, P. J. (2000). he Psychological Contract, Organisational Commitment and Job Satisfacction of Temporary Staff. Leadership \& Organisation Development, 21, 84-91.

Mehta, S., \& Maheshwari, G.C. (2013). Consequence of toxic leadership on employee job satisfaction and organisational commitment. Journal of Contemporary Management Research, 8(2), 1-23.

Mowday, R. T., Porter, L. W., \& Steers, R. (1982). Organisational linkages: The psychology of commitment, absenteeism and turnover. New York: Academic Press.

Naseer, S., Raja, U., Syed, F., Donia, M. B., \& Darr, W. (2016). Perils of being close to a bad leader in a bad environment: Exploring the combined effects of despotic leadership, leader member exchange, and perceived organisational politics on behaviours. The Leadership Quarterly, 27(1), 14-33.

Ngcamu, B. S. (2015). Leadership and transformation in a South African university, Problems and Perspectives in Management 13(1), 208-216.

Orunbon, N. O. (2021). Toxic Leadership Behaviour, Followership Characteristics and Productivity in Lagos Senior Secondary Schools, Nigeria. Unpublished Ph.D Thesis, Lagos State University.

Padilla, A., Hogan, R., \& Kaiser, R. (2007). The toxic triangle: Destructive leaders, susceptible followers, and conducive environments. The Leadership Quarterly, 18 (3); 178.

Rayner C. and Cooper C. ( 1997) Workplace bullying: Myth or reality - Can we afford to ignore it? Leadership and Organisation Development Journal 18(4): 211-214.

Raziq, A., \& Maulabakhsh, R. (2015). Impact of Working Environment on Job Satisfaction. Procedia Economics and Finance, 23, 717 - 725.

Salkind, N. J. (2016). Statistics for people (who think) Hate Statistics: Using Microsoft Excel. ( $4^{\text {th }}$ Eds). SAGE Publishers.

Samier, E.A. \& Schmidt, M. (eds.). (2010). Trust and betrayal in educational administration and leadership, Routledge, London.

Schmidt, A. A. (2008). Development and validation of the toxic leadership scale. Unpublished masters thesis, University of Maryland, College Park, MD.

Schyns, B., \& Schilling, J. (2013). How bad are the effects of bad leaders? A meta-analysis of destructive leadership and its outcomes. The Leadership Quarterly, 24(1), 138-158.

Shaju, M., \& Subhashini, D. (2017). A study on the impact of job satisfaction on job performance of employees working in automobile industry, Punjab, India. Journal of Management Research, 9(1), 117-130. 
Shantz, A., Alfes, K., Truss, C., \& Soane, E. (2013). The role of employee engagement in the relationship between job design and task performance, citizenship and deviant behaviours. The International Journal of Human Resource Management, 24(13), 2608-2627.

Siders, M. A., George, G., \& Dharwadkar, R. (2001). The Relationship of Internal and External Commitment Foci to Objective Job Performance Measures. The Academy of Management Journal 1(3)

Tavanti, M. (2011). Managing toxic leaders: Dysfunctional patterns in organisational leadership and how to deal with them. Human Resource Management, 134.

Tepper, B. J. (2000). Consequences of abusive supervision. Academy of Management Journal, 43(2), 178-190.

Tepper, B. J., Carr, J. C., Breaux, D. M., Geider, S., Hu, C., \& Hua, W. (2009). Abusive supervision, intentions to quit, and employees' workplace deviance: A power/dependence analysis. Organisational Behaviour and Human Decision Processes, 109(2), 156-167.

Tepper, B.J. (2007). Abusive supervision in work organisations: Review, synthesis and research agenda. Journal of Management, 33(3), 261-289.

Weaver, S. G., \& Yancy, G. B. (2010) The Impact of Dark Leadership on Organisational Commitment and Turnover. Kravis Leadership Institute. Leadership Review, 10,104 - 124.

Weberg, D. R., \& Fuller, R. M. (2019, February). Toxic Leadership: Three Lessons From Complexity Science to Identify and Stop Toxic Teams. Nurse Leader, 17(1), 22-26.

Webster, V., Brough, P., \& Daly, K. (2016). Fight, Flight or Freeze: Common Responses for Follower Coping with Toxic Leadership. Stress and Health, 346.

Wicker, M. (1996). Toxic leaders: When organisations go bad. Westport CT: Praeger.

How to cite this article:

Orunbon, N. O., Lawal, R. O., Isaac-Philips, M. M., \& Salaudeen, R. I. (2022). Toxic Leadership, Teachers' Job Satisfaction and Organisational Commitment in Lagos State Tertiary Institutions, Nigeria. Journal of Educational Sciences, 6(1), 66-78. 